Zagadnienia Rodzajów Literackich, LXI, z. 2

PL ISSN 0084-4446

DOI: https://doi.org/10.26485/ZRL/2018/61.2/10

AnNa WendorfF

University of Łódź*

\title{
Gender in Translation - as Exemplified by Michał Witkowski's Lubiewo Translated into Spanish
}

\begin{abstract}
This article attempts a closer look at the issue of grammatical gender in translation. The analysis of this concept is based on Michał Witkowski's novel Lubiewo (Korporacja Ha!art, Kraków, 2005 [2006]) and its Spanish translation by Joanna Albin (Lovetown, Anagrama, Barcelona, 2011). The author of the article aims to analyse problems of grammatical gender translation which stem from the differences between the Polish and Spanish grammar systems, and how the gender specific elements in the Polish text were rendered in the target language, especially in the fragments in which Spanish did not have the grammatical gender equivalent and the translator had to compensate for it in a different fragment.
\end{abstract}


* Zakład Literatur Hiszpańskojęzycznych, Katedra Filologii Hiszpańskiej, Uniwersytet Lódzki

ul. Pomorska 171/173, 90-236 Łódź

e-mail: anna.wendorff@uni.lodz.pl

Scholarship holder of the Scientific Award of the Foundation of the University of Lódź in 2017. 
The standards of grammatical gender and gender in general in translation have been widely tackled especially in the context of English to Polish translations, invoking the difficulty that Polish grammatical gender poses in texts translated from genderless languages. The critique on this subject features such articles as: Krzysztof Hejwowski's article titled Płeć i rodzaj gramatyczny w przekładzie (Sex and Gender in Translation) (2011: 175-181), Translation as Rewriting. The Problem of Grammatical Gender in the Polish Translation of Jeffrey Archer's 'You'll Never Live to Regret It' by Izabela Szymańska (2008: 127-158) or Putapki ptciologocentryzmu: esej o przektadaniu 'Written on the Body' Jeanette Winterson na jesyle polski przepleciony kilkoma dygresjami na tematy Shakespeare'a (The Traps of Sex-logocentrism: an Essay on Translating Jeanette Winterson's 'Written on the Body' into Polish and a few Remarks on Shakespeare) by Zbigniew Białas (2006: 51-58). These authors set out to analyse the translations into the Polish language of such works as the novel Written on the Body (1994) by Jeanette Winterson (Zapisane na ciele in translation by Hanna Mizerska), the story entitled You Will Never Live to Regret It by Jeffrey Archer from the volume Twelve Red Herrings (1994) (Dwanaście fatsaynych tropów, translated by Krzysztof Sokołowski and Michał Wroczyński) or the novel entitled Gentlemen and Players (2005) by Joanne Harris (Díentelmeni i gracze translated by Katarzyna Kasterka).

At the beginning of his article, Hejwowski refers to Wstep do teorii ttumaczenia (1957) written by a renowned Polish linguist and translator, Olgierd Wojtasiewicz. He stresses the fact that the notion of grammatical gender is considered by this linguist to be a possible source of untranslatability of texts (Hejwowski 2011: 175). He, then, goes on to describe a situation when an author might want to conceal the character's sex from the reader, providing Shakespeare's Sonnet 16 and a story entitled You'll Never Live to Regret It by Jeffrey Archer as examples. When talking about the latter, he supports himself with Izabela Szymańska's reflections from her article Translation as Rewriting. The Problem of Grammatical Gender in the Polish Translation of Jeffrey Archer's 'You'll Never Live to Regret It' (Hejwowski 2011: 176-177), which will be discussed later on. Hejwowski also makes a reference to Jeanette Winterson's Written on the Body, this time in the context of Zbigniew Białas' article entitled Pułapki ptciologocentryzmu: esej o przektadaniu 'Written on the Body' Jeanette Winterson na jesylk polski przepleciony kilkoma dygresjami na tematy Sbakespeare'a (Hejwowski 2011: 178-179), 
which will also be discussed later on. Hejwowski continues by listing translation techniques which allow the writer to conceal the narrator's sex including: changing a sentence with a subject into the one without it, a change into the present or future tenses, changing the personal pronoun into the possessive one, substituting the pronoun with the noun that refers to both genders, moving the subject into the object or adverbial positions together with 'subjectification' of the adverbial, the object or adding a new subject (Hejwowski 2011: 179-180).

In her article, Szymańska analyses two translations (the translation and the revised version) of Jeffrey Archer's story You'll Never Live to Regret It authored by Krzysztof Sokołowski and Michał Wroczyński, which appeared in the Twelve Red Herrings volume, and offers her own retranslation. She concentrates on how the literary device called the red herring which means something misleading - functions in the translation. In this story, not disclosing the sex of one of the characters in its first part is the red herring. She goes on to discuss, both in general and using specific examples from the text, possible translation solutions how to conceal the character's sex. Among other things, she mentions: the use of present tense of imperfective verbs, the synthetic future of perfective verbs and the analytic future of imperfective verbs with the infinitive; the use of the 3rd person plural form and not the impersonal form; changing from direct speech to free indirect speech; changing the noun from quotative frame to the appellative; using only two declensions: the Nominative and the Vocative; altering masculine and feminine forms; nominalization; introducing the surname; changing the perspective from which the story is told e.g. from another character's point of view; using ellipsis or a 'film cut' etc. (Szymańska 2008: 138-152). She also stresses that «the translator's 'local' decisions will have to be reconsidered at the 'global' level of plot construction and narration...» (Szymańska 2008: 128). All these considerations lead her to a reflection on translator's freedom and, as a result, the use of unconventional and creative translation methods, including adoption and rewriting. In her opinion, all such methods are allowed if they are the only way to achieve functional equivalence, as was the case in Archer's story.

Białas opens his discourse by saying that it is impossible to remove the sex/gender from the translation (Białas 2006: 51). Although he is aware of the many linguistic experiments that translators made to remain detached from the sex/gender, in his view, they are a controlled escape from the language and from identity building, and not a way towards creative language construction (Białas 2006: 51-52). He continues by enumerating areas in which we can deal with translation gender in English-Polish translations. These areas include: onomastics, some types of literary and cultural symbols, and ideological words characteristic of a given culture (Białas 2006: 53). He, then, goes on to analyse the Polish translation of Jeanette Winterson's Written on the Body authored by Hanna Mizerska. The book's semantic dominant is omitting to specify the sex of the narrator. Białas engages into a discussion with some arguments with which the translator prefaced her work, such as, concealing the narrator's sex by using the first person of the present tense in Polish. He challenges the indicators of femininity and masculinity characterised by the translator and, more importantly, that marking the sex of the narrator was a necessary compromise (Białas 2006: 54-58). At the same time, he is aware of the fact that some English linguistic structures are untranslatable into Polish, because it is impossible to eliminate sex and gen- 
der specific elements. He concludes by saying that Jeanette Wintersons' novel will never successfully exist in Polish.

Rarely has the translation of grammatical gender and gender in general figured in Polish-Spanish translations. One salient exception here is Lubiewo (2005) by Michał Witkowski and its translation into Spanish entitled Lovetown (2011) by Joanna Albin. And this work will be the subject of my translation analysis.

But first, the term 'gender' itself merits more definition. The year of 1979 was when the term 'gender' was coined by Rhonda Unger (Unger 1979: 1085-94), and 1990 saw the publication of one of the most important works of feminist theory, which defined the concept of gender, queer and sexual politics in culture: Judith Butler's book entitled Gender Trouble: Feminism and the Subversion of Identity. The literature on this issue distinguishes between two terms: sex and gender. Gender, as opposed to the biological sex, is defined as a cultural distinction that is constructed socially. It could be described as a set of characteristics, attributes, attitudes and social roles that culture has ascribed to the man and the woman; 'the kind of information that serves as a basis for people to form opinions and initiate behaviour in social interactions' (Mandal 2007: 8, A.W. trans.). Society distinguishes between femininity and masculinity, both of which have two definitions: the biological one and the cultural one. The former is granted to us when we are born, while the latter is acquired in the process of up-bringing. Gender theory has its origin in feminist philosophy of women's studies of the 1970s when the concept of femininity was replaced with a broader one - gender. It is worth noting that gender theory and gender identity in gender studies developed after Poland just had its political system transformed, which is why it should come as no surprise that the country was focused on other issues and problems, on implementing changes and reforms, and that gender studies did not find fertile breeding ground at that time.

A milestone in dealing with sex and gender issues in Polish belles-lettres was set by Lovetown by Michał Witkowski, which presents the underworld of the late communist period in Poland. In his novel, the author engages in a play with grammatical, cultural and social genders, 'constructing a new genre of the homosexual language' (Marecki 2006: 218).

In Lovetown, its author refers explicitly to gender studies, both at the level of metaliterature as well as the language code. In Międzyzdroje, Witkowski - the narrator — coaxes many a single gentleman into narrating his/her own story, just like in Salo by Pasolini, to organise a 'faggot Decameron' (Witkowski 2006: 80). He also mentions being invited to a gender or queer conference at the University of Poznań where he would meet German Ritz (a renowned Swiss Slavist, a researcher of the so-called delicate issues, among other things, Polish homosexual literature). Another well-known figure at the conference would be Grażyna Borkowska (professor at the Institute of Literary Studies of the Polish Academy of Sciences, PAN, whose main field of interest is feminist criticism), who was going to give a feminist lecture on the body based on Judith Butler (Witkowski 2006: 152). The issue of gender is also visible at the language level. Witkowski plays with grammatical gender, and consequently with the categories of femininity and masculinity. Homosexual characters in Lovetown fall into two categories: those who always refer to themselves in the masculine gender, and those who tend to speak of themselves in the feminine gender, but depending on 'the mug they are fitted with', they choose either of the genders. The group from Poznań, that is emancipatory, fight for homosexuals' rights to contract matrimony 
and adopt children and take part in equality parades, speak of themselves using the masculine gender (Witkowski 2006: 146). The group of swish dames speak of themselves in the feminine gender. Its members do not really want to be females; they only want to put on airs of femininity the way they imagine women to be like: they flap their hands, they squeal, and their language is permeated with exaggerations and diminutives (Witkowski 2006: 11-12). This group features, among others, the narrators: Patricia and Lucretia, who have no match for being dramatic and who talk to other members of the group using female nicknames (below Polish nicknames from the source language and their equivalents in the target language: Śnieżka/La Blancanieves, Literatka/La Literata, Wężowa/La Serpiente, Kapielowa/La Bañista etc. ${ }^{1}$ ), or female counterparts of their masculine names. In most cases, the Spanish translation relies on the loan words as the following few examples illustrate: Lucja, Patrycja, Zdzicha or Maciejowa. And sometimes, just like with the Polish 'Michaśka' translated into Spanish as 'Michałina', we see the use of the suffix -ina, which is most commonly used to denote nationality or characteristics in female form (the male form being -ino). It seems to be the translator's intention because, on the one hand, the Polish name form is preserved, while on the other, the Spanish reader is perfectly aware of the female form. Polish old-time faggots, although being men biologically, play in being Baroque queers, far from being men (Witkowski 2006: 322), which is directly reflected in the language they use. As Witkowski observes on his webpage, Lovetown is not - as some of its critics would have it — so much:

[A]bout gays, as about certain gay sub-group, commonly known as 'faggots', and also about certain quaint habits that this community has formed over the years. My interest is mainly in the specific female roles that are assumed, and the reason why these roles and not others. I am not concerned with middle class gays, but precisely those 'obnoxious, filthy, bad ones' because all that's left to them is confabulation, language, and fabrication; and that's all they have to make do with. The middle class gays have their stable relationships, houses with gardens and lawnmowers, while these have nothing. They are the utter dregs of the society: not only gay, but also law-breakers: thieves, prostitutes, slappers. If they can hold a job, it's usually sedentary. So they sit. And while they sit in some dingy security or prison guard booth or elsewhere, they daydream and fantasise about most wondrous things - that is why they make such attractive literary characters. The reality, no matter how horrid, is quite apart, because they inhabit their own surreal world. Even if they talk about one another behind their backs, they satiate an otherwise unseen need for narration. These faggot bohemians seek haven from madness in theatre, camp, and surrealism. They rise in revolt against all social hierarchies: they don't see repulsion where others see it; and the middle class world looms before their eyes in all its meaningless pink colours. Thus, they make the 'widely understood' good taste and 'generally received' morals relative... They are a slap in the face of totalitarianism and all that's generally accepted and sanctified. (Witkowski 2012; A.W. trans.)

Just like Miron Białoszewski in his original novel Donosy z. rzeczymistości (Reports of Reality, 1973), also Witkowski cultivates queer 'live speech', and following Butler (1990), we can safely say that his characters fall into gender trouble (Gender Trouble: Feminism and the Subversion of Identity translated into Polish as Uwiktani w Ptec). Thus, it merits investigating how such gender entanglement is rendered in other languages; the fact that the novel has been

1 The English nicknames are: Snowflake, La Belletriste, Anaconda and La Douche respectively. 
translated into 20 languages is also worth noting. In this paper, it is the Spanish translation that is of interest to me. Lovetown came out in Spain in 2011, that is, 6 years after the publication of the original; it was published by Anagrama and brilliantly translated by Joanna Albin under the same title as the English version by William Martin, which was nominated for The Independent Foreign Fiction Prize.

The comparison of gender specific elements in Polish and Spanish first necessitates considering the grammar systems of both languages. Just as Ewa Gruszczyńska observes in her article Wplyw gramatyki na literature w kontekśsie pręeleladu:

The fact that the grammar system, and grammar categories especially, influence the form and the content of a discourse, including literary texts, has been borne out on numerous occasions by linguists dealing with issues that span such fields as semantics and inflexion, semantics and morphology, or semantics and syntax. If we agree about a relationship between grammar and semantics within one language, we must also agree on there being an additional dimension to that relationship when two languages interconnect in the process of translation; a dimension which is critical for the form and content of the target text, i.e. the translation. (Gruszczyńska 2011: 165; A.W. trans.)

For this part, Olgierd Wojtasiewicz adds that sometimes 'language structural features impact the information content in a given text'. And so he argues that 'the correct grammar forms, and in translation, the choice of appropriate equivalents of the source text forms cannot be considered formal actions' as they can lead to either enriching or impoverishing the information in the text (Wojtasiewicz 1957: 31-32).

Both these observations can be applied to the translation of 'the diaries of faggot revolt' (a term created by Witkowski, http://www.michalwitkowski.pl/content/lubiewo) into Spanish. The author alternates in the use of feminine and masculine forms when he refers to the sterner sex, which — as Martin notices in the Translator's Afterword (Witkowski 2010: locations: 3712-23) — makes Lovetown's identity volatile in nature: 'where the order of things is quickly subverted and identity is never fixed.' However, Simon Sherry adds: 'Gender is an element of identity and experience which, like other cultural identities, takes form through social consciousness' (Sherry 1996: 5). It should be added here that the Polish language is conducive to such plays, and even intensifies them, on account of its declension and conjugation possibilities. The Spanish verbs do conjugate, having various conjugation models, though they do not distinguish between gender forms, like in Polish (e.g. singular past tense of 'pracowałem' for masculine / 'pracowałam' for feminine or the plural past tense 'pracowaliśmy' for masculine / 'pracowałyśmy' for feminine). The gender terminations in Polish are found in the Past, Future Perfect, and Past Perfect Tenses as well as in adjectival participles. However, worth remembering is the fact that not all Polish verbs have different gender forms. There are also those that have only one inflected form, i.e. 3rd person singular e.g. 'zagrzmiało'. In Spanish, gender can also be determined by the context or by the subject e.g. a personal pronoun 'on'/'ona' ('él'/'ella') or the plural form 'ellos'/'ellas'. The interesting thing is that unlike Polish, Spanish 1st and 2nd persons plural have two forms ('nosotros'/'nosotras' and 'vosotros'/'vosotras'), while Polish has two forms in the 3rd person singular, which in Spanish assumes only one form 'usted'

2 'He'/'She'. 
(note that 'usted' refers to a 2nd person singular [polite 'tú'] although grammatically it is a 3rd person). Grammatical gender is a crucial category of the verb as it is used to signal the syntactic relationships between the elements of an utterance. Thus, we can speak of a dependent category as its form depends on the form of the qualified words. By contrast, declension is about assigning individual cases their corresponding inflected endings. In the Polish language, nouns, adjectives, numerals, and substantive and adjectival pronouns are declined, i.e. their form matches the form of the noun they go with. The Spanish language, on the other hand, does not have declension. The grammatical gender that is of key interest in this article can be defined in Polish as »a characteristic of all inflectional parts of speech, except for substantive pronouns 'ja', 'ty', 'my', 'wy'3 , and the reflective pronoun 'się' (-self), which signals the agreement between syntactic elements of an utterance« (Bańko 2008: 119, entry's author: Hanna Jadacka A.W. trans.). Polish nouns have one of three gender forms: masculine, feminine or neuter. A more detailed classification features also masculine-personal, masculine-animate, masculine-inanimate, feminine and neuter in the singular, and masculine-personal and non-masculine-personal in the plural. Spanish nouns, however, have only two genders: masculine and feminine (the gender depends on the ending or the meaning) and depending on the gender, they go together with a specific form of articles, adjectives or pronouns.

Let us now try to analyse how the above information on the grammar systems of both languages influences the translation of Polish Lubiewo into Spanish, because, as Sherry points out: 'taken together, translation and gender seem to offer a particularly attractive matrix through which to investigate issues of identity in language' (Sherry 1996: X). Lovetown opens up when Michal — the reporter man — takes the lift to get to the fourth floor of a dreary socialist apartment block to hear the story of two faggots: Patricia and Lucretia. As we learn on the first page of the book, 'Patrycja i Lukrecja sa juz starymi facetami i w ich życiu wszystko dawno się skończyło' (Witkowski 2005: 9, underlining added) / 'Patrycja y Lukrecja son dos tipos ya viejos, cuyas vidas ya han llegado al final del trayecto' (Witkowski 2011: locations 67-80) ${ }^{4}$. As we can see, the names of the characters were left as they appear in the source language since their endings indicate the feminine gender and the Spanish reader will know that they are female names - the more so because Spanish has similar names: Patricia and Lucrecia. Thus, just like in the source text, the Spanish version preserved the transition between the feminine gender (the characters' names: Patrycja, Lukrecja) to masculine gender (dos tipos viejos); in Spanish it is the ending — o that suggests the gender — see 'tipo'/'viejo' as opposed to the feminine 'tipa'/'vieja'. Moreover, 'tipo' is an equivalent of the word 'facet' (guy) for two reasons. First, the register of the word is colloquial, and second, it does not create ambiguity as far as gender is concerned. If the translator had used e.g. the word 'hombre', apart from changing the register, it would be ambiguous as this Spanish word can denote both 'a man' in general and also 'a man' as opposed to a 'woman'. The Polish possessive adjective 'ich' (their) from the second part of the sentence in Polish corresponds to the 3rd person plural regardless of gender. The translator in the Spanish text, however, used the relative

3 'T', 'You', 'We', 'You'.

4 'Patricia and Lucretia are already old men; whatever lives they once enjoyed are long over and done with' (Witkowski 2010: locations 13-24). 
pronoun 'cuyo' (whose), which accommodates the singular/plural and gender forms, and additionally agrees not with the owner, but with the thing that is owned, in this case 'cuyas vidas'. Although the perspective was slightly changed from 'in their lives' to 'their lives', it seems to be an interesting move to suggest how transient and imprecise the feminine and masculine categories are in Witkowski's work.

Casting a glance at the above examples from the two versions might create a false impression that Polish and Spanish do not pose great translation difficulties as far as grammatical gender is concerned. Let us, however, take a look at other gender specific fragments. Past tense is definitely problematic in translation, like in the following Polish sentence and its Spanish equivalent: 'Lukrecja był kiedyś germanista, ale nigdzie długo nie mógł zabawić, ciagle przysparzał kłopotów, podrywał uczniów i w końcu zaczą utrzymywać się tylko z korepetycji' (Witkowski 2006: 10) / 'En otros tiempos Lukrecja fue profesor de alemán, pero no conseguía echar raíces en ningún sitio, era una constante fuente de problemas porque les tiraba los tejos a los alumnos, al final acabó viviendo de dar clases particulares' (Witkowski 2011: locations 80-94) ${ }^{5}$. Past tense endings of Polish verbs depend on gender, while in Spanish there's only one form. Compare e.g. Polish form 'był' (masculine) / 'była' (feminine $)^{6}$ and their corresponding Spanish form 'fue' which does not depend on gender. Thus, the translator cannot use the verb to mark the gender form, and the verbs refer back to the feminine subject Lucretia, and so, according to Polish grammar rules, they would assume a feminine ending, and not — like in Witkowski's text — a masculine one. In both, the Polish and Spanish text, the masculine gender form is highlighted e.g. on the job: the Polish word 'germanistą' (as opposed to feminine 'germanistka') and in Spanish: 'profesor de alemán' (not 'profesora'). The translator, just like the author, plays with gender and instead of the Polish 'przysparzal problemów', she says that he was a source of problems ('era una... fuente de problemas') and the word 'fuente' is feminine in Spanish. So, the translation preserves the play with grammatical gender: on the one hand, feminine gender (Lukrecja; una fuente), on the other, masculine gender (profesor). The Spanish reader is also introduced into this gender play by numerous author's comments. See the Polish fragment: 'Mówią o sobie w rodzaju żeńskim, udaja kobiety, do niedawna podrywali facetów w parku, pod Opera i na dworcu' (Witkowski 2006: 11) / 'Hablan de sí mismos en femenino, fingen ser mujeres y hasta hace poco ligaban con tíos en el parque, en los alrededores de la Ópera y en la estación de tren' (Witkowski 2011: locations 108-123) ${ }^{7}$. This translation is not as great a challenge as Jeanette Winterson' Written on the Body (Vintage International, New York, 1994), where obscuring the sex of the narrator is the semantic dominant. Polish translator, Hanna Mizerska (Zapisane na ciele, Rebis, Poznań, 2000), finally translated the novel with the narrator as a woman. All the same, it should be stressed here that Polish, compared to Spanish, allows for more language plays due to its grammar potential, also in case of gender.

5 'Lucretia had once been a German teacher, but he could never keep a job for long; he was always landing himself in trouble by making moves on his students, until finally he ended up working as a private tutor' (Witkowski 2010: locations 24-34).

6 was.

7 'They refer to each other as she and her, call each other sister or girl, and it wasn't all that long ago that they were still picking up men — in the park, behind the opera house, and at the train station' (Witkowski 2010: locations 44-54). 
The masculine gender in the Spanish version is also accentuated by the use of an adjective in the masculine form. Let us compare the following sentences in the two languages: 'Patrycja leżał pijany z głową w szczynach i myślał, że już się nie wydobędzie' (Witkowski 2006: 10) / 'Patrycja yacía borracho con la cabeza en un charco de meados, resignado a no salir ya nunca de allí' (Witkowski 2011: locations 71-85) ${ }^{8}$. In the first part of the sentence, the adjective is directly determined by an equivalent structure in Polish ('leżal pijany' - 'yacía borracho'). In the second part of the sentence, the translator deliberately stuck to the adjective 'resignado' (masculine) instead of introducing a verb, which, as was mentioned, does not distinguish gender forms.

The feminine gender was obtained e.g. when the translator introduced an article, just like in the following sentence: 'Durante esas noches se imaginaba que era una cortesana del siglo XVII, con un enorme miriñaque y una alta peluca, que iba a ver a su amante en carroza' (Witkowski 2011: locations 85-99) / 'Wtedy wyobrażała sobie, że jest barokowa damą, ma wielką krynolinę, wysoką perukę i jedzie karetą do kochanka’ (Witkowski 2006: 10) ${ }^{9}$. The Spanish Imperfecto form of the verb 'imaginarse', which is not gender specific, ('se imaginaba') is compensated by the indefinite feminine article: 'una'. It can be observed, however, that the source language form ('kochanek') clearly determines the sex of the woman's partner, while the Spanish form 'amante' (the same for masculine and feminine gender) can refer to both sexes. I believe that this was a conscious choice of the translator (she could have after all used the masculine form 'querido' instead of 'amante' to determine the sex), who is aware of the gender entanglement of the characters who are impossible to categorize either as women or as men. The translator aims to compensate for gender translation losses in the Spanish version and she always finds a solution to make up for a given gender form in another fragment with another part of speech in the correct gender form. And, more importantly, her translation is rendered with utmost care for all, even minute, details — not only connected with grammatical gender.

Another way to compensate for the feminine verb form in the Spanish version is to add a personal pronoun: 'ella'. In the original, there is: 'Trzeba było podpisać kontrolkę, trzeba było wracać, znowu ktoś coś od niej chciał i znowu była leniwa i krnabrna' (Witkowski 2006: 10-11), while in the Spanish translation, the fragment is thus rendered: 'Había que fichar, había que regresar, de nuevo todo el mundo le pedía algo y ella volvía a ser perezosa y obstinada' (Witkowski 2011: locations 85-99) ${ }^{10}$. Here, the past tense 3rd person singular verb, which has a feminine form: 'była' is compensated for by 'ella'. The feminine gender is signalled to the reader also by the use of adjectival forms, which, both in the source and target languages, agree in gender forms (leniwa - perezosa and krnabrna — obstinada). Yet, Polish also has another element which indicates the feminine gender, namely, the substantive pronoun 'niej', which is translated by the Spanish indirect object 'le', which can refer to both, the feminine as well as the masculine gender. In order

\footnotetext{
8 'Patricia was sprawled out, drunk, his head in a pool of piss, thinking he'd never get back on his feet' (Witkowski 2010: locations 28-39).

9 'Then she would fantasise that she was a Baroque lady wearing an enormous crinoline and a tall wig, taking a carriage to see her lover...' (Witkowski 2010: locations 33-43).

10 'She had to clock off, she had to go back; once again people would be making demands of her, and once again she would be lazy and insubordinate in return' (Witkowski 2010: locations 38-49).
} 
to further accentuate the gender, the element 'a ella' might be added to 'le pedía' ('le pedía a ella'), but such an operation is not necessary because the second part of the sentence clearly indicates the feminine gender.

The feminine gender is also restored in the novel with the direct object 'la', just like in the following Spanish sentence: 'Ésa fue mi reflexión filosófica y Lucja la Bañista, a la que se lo conté, me dio la razón' (Witkowski 2011: locations 128-43) / 'Taka mnie refleksja filozoficzna natchnęła i Łucja Kąpielowa, której się zwierzyłam, to potwierdziła' (Witkowski 2006: 13) ${ }^{11}$. The feminine gender is mainly marked on the subject: Lucja la Bañista, but the use of the object 'la' makes it even more prominent.

Gender compensation in the Spanish version is also rendered with the use of emotional expressions — more precisely — implicit expressive forms. The Polish word 'Jezu!' (Witkowski 2006: 18), which is an exclamation conveying various emotional states and attitudes, is converted into another semi-religious expression, which is feminine in gender, '¿La Virgen!' (literally: the Virgin, which refers to the Blessed Virgin Mary, Mother of Jesus Christ) (Witkowski 2011: locations 205-221). It is a deliberate choice even despite the fact that the Spanish language has an exclamation 'Jesús', which, depending on the context, can denote admiration, pain, fear, regret or compassion and would be a perfect equivalent here.

The translator of the Spanish Lovetown is also mindful of the grammatical gender of the vocabulary describing homosexuals. If Witkowski in his novel uses the word 'ciota' (faggot), the translator uses the feminine form 'la marica' which derives from the masculine 'maricón'. It is also interesting how the gender play is maintained in the use of words describing certain professions. Let us have a look at the following fragment: 'Aha, a Hrabinę zabili dużo wcześniej, w siedemdziesiątym dziewiątym i była z zawodu babcia klozetowa. A właściwie dziadkiem. A zreszta — właśnie że babcia!' (Witkowski 2006: 16); and its corresponding translation: 'Ah sí, que a la Duquesa la mataron mucho antes, en el setenta y nueve, y trabajaba de señora de la limpieza. O sea, señor. Aunque, en verdad, jseñora precisamente!' (Witkowski 2011: locations 168-183) ${ }^{12}$. The gender play is continued in the translation, as 'babcia klozetowa' is rendered as 'señora de la limpieza', while 'dziadek (klozetowy)' from the original version becomes 'señor (de la limpieza)' in the translation. Although the colloquial register of the word 'babcia klozetowa' ${ }^{13}$ was not preserved in Spanish, because 'señora de la limpieza' is neutral, the grammatical gender play on the words denoting profession was maintained, which is undoubtedly of central importance in this novel.

It should be noted here that apart from the grammatical elements, the gender element is also visible in the lexical ones, that is, in the specific expressions concerning homosexuals, as well as their own social dialect, full of exaggerations, augmentations, exclamations etc. - the so-called gay lisp, which finds its equivalent in the target language and culture. This is one example: "'Przeginanie się to udawanie kobiet — jakimi je sobie wyobrażaja — wymachiwanie rękami, piszczenie, mówienie 'ależ przestań' i 'Boże, Bożenka'. Albo podchodzenie do miśka, kładzenie mu ręki pod brodę i mówienie: — Główkę, szczeniac-

11 'So I'm having all these deep philosophical thoughts, see, and Lucia La Douche, who I share them with, completely agrees' (Witkowski 2010: locations 82-92).

12 'Right, so the Countess was killed long before that, in '79. She was a grandfather, and she worked as a toilet lady — so I guess that makes her a grandmother!' (Witkowski 2010: locations 121-131).

13 'toilet granny'. 
zku, wyżej trzymaj, jak do mnie rozmawiasz. - Wcale nie chcą być kobietami, chcą być przegietymi facetami (Witkowski 2006: 12) / "Sacar pluma’ es fingir ser mujeres, según la imagen que de ellas tienen: gesticular, chillar, repetir 'Oh, ya basta' y 'Dios mío, chica'. $\mathrm{O}$ acercarse a un guapito, levantarle la barbilla con un dedo y decir: 'Mírame a los ojos cuando hables conmigo, majete'. Para nada quieren ser mujeres, quieren ser tíos con pluma" (Witkowski 2011: locations 109-23) ${ }^{14}$. The expression that poses the biggest translation problems is 'przegięty ${ }^{15}$, which the translator renders as the word 'pluma', and integrates it in other expressions, such as: 'sacar pluma', 'tíos con pluma', 'toda su pluma', 'iesta pluma ya no se me quita!', 'con su pluma justa' or 'la teoría de la pluma'. The characters fall into two categories: heterosexuals — 'sin pluma' — or homosexuals — the ones 'con pluma'. And here again, the translator seems to have found the best option as the word 'pluma' in the language of the street refers to effeminate men, both the way they speak and their gestures. However, an in-depth analysis of the gay speak in Lubiewo by Witkowski and its Spanish equivalent is material for a more detailed study beyond the scope of this paper.

To sum up, all the fragments of the Spanish translation quoted in this article are sound evidence of how well Joanna Albin, the translator of the Spanish version of Lovetown, recognized the semantic dominant of the novel, i.e. the meaning of gender and sex issues. She also persisted throughout the whole text in preserving the dominant, accentuating grammar elements or the ones that carry meaning, and are crucial to the overall message. She compensated for any change, ambiguity and imprecision or vagueness of the grammatical gender by using a range of translation techniques, which was the key to the perfect rendition of this novel.

14 »Being 'dramatic', 'camping it up', and 'being swish' mean acting like a woman, whatever they understand by that. Apparently it means flapping their hands and squealing, saying things like 'Oh stop!' and 'Christ, Christina!', or going up to a cute lad, holding their bent wrists in his face, and saying, 'Sit up straight, puppy dog, when you're talking to me!' They don't want to be women at all; they want to be swishy men« (Witkowski 2010: locations 62-72). 


\section{Bibliography}

Archer Jeffrey (1994), Twelve Red Herrings, Harper Collins, London.

- (1994), Dwanaście fatszynych tropów, trans. K. Sokołowski, M. Wroczyński, Prima, Warszawa.

Bańko Mirosław (ed.) (2008), Poprawna polszcryzna. Hasła problemowe, Naukowe PWN,

Warszawa.

Basiuk Tomasz, Ferens Dominika, Sikora Tomasz (eds.) (2002), Odmiany odmieńca / A Queer

Mixture, Wydawnictwo Naukowe Śląsk, Katowice.

Białas Zbigniew (2006), Pułapki ptciologocentryzmu: esej o przekładaniu 'Written on the Body' Jeanette

Winterson na jezylk polski przepleciony kilkoma dygresjami na tematy Shakespeare'a [in:] Pteć w prze-

kładzৃie, ed. P. Fast, "Śląsk” Sp. z o.o. Wydawnictwo Naukowe, Wydawnictwo Wyższej

Szkoły Lingwistycznej, Katowice-Warszawa-Częstochowa, pp. 51-58.

Białoszewski Miron (1973), Donosy rzeczymistości, PIW, Warszawa.

Butler Judith (1990), Gender Trouble: Feminism and the Subversion of Identity, Routledge, New York.

- (2008), Uwikłani w pteć, trans. K. Krasuska, Wydawnictwo Krytyki Politycznej, Warszawa.

Chamberlaine Lori (1988), Gender and the Metaphorics of Translation, "Signs: Journal of Women in Culture and Society", vol. XIII, no. 3, pp. 454-472.

Czapliński Przemysław, Anna Mizerska (eds.) (2012), Kamp. Antologia przełkładów, Universitas, Kraków.

Fast Piotr (ed.) (2006), Pteć w przekeładzie, "Śląsk" Sp. z o.o. Wydawnictwo Naukowe, Wydawnictwo Wyższej Szkoły Lingwistycznej, Katowice-Warszawa-Częstochowa.

García Mouton Pilar (2000), Cómo hablan las mujeres, Arco Libros, S. L., Madrid.

Gruszczyńska Ewa (2011), Wplyw gramatyki na literature w kontekśsie przekładu [in:] Translatio i literature, ed. A. Kukułka-Wojtasik, Wydawnictwo UW, Warszawa, pp. 165-174.

Harris Joanne (2005), Gentlemen and Players, Doubleday, London.

- (2006), Díentelmeni i gracze, trans. K. Kasterka, Prószyński i S-ka, Warszawa.

Hejwowski Krzysztof (2011), Płé́ i rodzaj gramatyczny w przektadzie [in:] Translatio i literatura, ed. A. Kukułka-Wojtasik, Wydawnictwo UW, Warszawa, pp. 175-181.

Heydel Magda (ed.) (2011), "Przekładaniec", no. 24, Myśl feministycz̨na a pržekład, Wydawnictwo UJ, Kraków.

Karwatowska Małgorzata, Szpyra-Kozłowska Jolanta (2005), Lingwistyka płci. Ona i on w jezyku polskim, Wydawnictwo UMCS, Lublin.

Łaziński Marek (2006), O panach i paniach. Polskie rzeczowniki tytularne i ich asymetria rodzajowo-ptciowa, Naukowe PWN, Warszawa.

Mandal Eugenia (ed.) (2007), W keregu gender, Wydawnictwo Uniwersytetu Śląskiego, Katowice. Marecki Piotr (ed.) (2006), Tekstylia bis. Stownik mtodejpolskiej kultury, Korporacja Ha!art, Kraków. Martínez García Adela (ed.) (2004), Cultura, lenguaje y traducción desde una perspectiva de género, Universidad de Málaga, Málaga.

Mizielińska Joanna (2006), Pteć, ciało, seksualność. Od feminizmu do teorii queer, Universitas, Kraków. Nowosad-Bakalarczyk Marta (2009), Płeć a rodzaj gramatyczny we wspótczesnej polszçyźnie, Wydawnictwo UMCS, Lublin.

Pawlik Janusz (2001), Selección de problemas de gramática española, Wydawnictwo UAM, Poznań. Santaemilia Ruiz José et al. (eds.) (2003), Género, lenguaje y traducción, Universitat de València, Valencia. 
Sherry Simon (1996), Gender in Translation: Cultural Identity and the Politics of Transmission, Routledge, London-New York.

Szymańska Izabela (2008), Translation as Rewriting. The Problem of Grammatical Gender in the Polish Translation of Jeffrey Archer's 'You'll Never Live to Regret It' [in:] DUET Encounters, eds. M. Grzegorzewska, A. Korzeniowska, Institute of English Studies, University of Warsaw, Warsaw, pp. 127-158.

Unger Rhoda (1979), Toward a Redefinition of Sex and Gender, "American Psychologist", Vol. 34, No. 11, pp. 1085-94.

Winterson Jeanette (1994), Written on the Body, Vintage International, New York.

Witkowski Michał (2000), Zapisane na ciele, trans. H. Mizerska, Rebis, Poznań.

- (2006), Lubiewo, Ha!art, Kraków.

- (2010), Lovetown, trans. W. Martin, Portobello Books, London.

- (2011), Lovetown, trans. J. Albin, Anagrama, Barcelona.

— (2012), http://www.michalwitkowski.pl/content/lubiewo [access 4.01.2018].

Michat Witkowski. Unofficial website, http://www.michalwitkowski.pl [access: 4.01.2018].

Wojtasiewicz Olgierd (1957), Wstẹp do teorii ttumaczenia, Zakład im. Ossolińskich, WrocławWarszawa. 